\title{
Distribution of Leaf-Feeding Beetles and Bean pod mottle virus (BPMV) in Illinois and Transmission of BPMV in Soybean
}

T. R. Mabry, H. A. Hobbs, T. A. Steinlage, B. B. Johnson, and W. L. Pedersen, Department of Crop Sciences, J. L. Spencer and E. Levine, Illinois Natural History Survey, S. A. Isard, Department of Geography, and L. L. Domier and G. L. Hartman, USDA-ARS and Department of Crop Sciences, University of Illinois, 1101 W. Peabody Drive, Urbana 61801

\section{ABSTRACT}

Mabry, T. R., Hobbs, H. A., Steinlage, T. A., Johnson, B. B., Pedersen, W. L., Spencer, J. L., Levine, E., Isard, S. A., Domier, L. L., and Hartman, G. L. 2003. Distribution of leaf-feeding beetles and Bean pod mottle virus (BPMV) in Illinois and transmission of BPMV in soybean. Plant Dis. 87:1221-1225.

Bean leaf beetles (BLB; Cerotoma trifurcata) were collected in soybean (Glycine max) fields in 58 and 99 Illinois counties surveyed during the 2000 and 2001 growing seasons, respectively. In 2000 , BLB counts were highest in the central portion of the state. BLB counts were lower the following year, but were more uniformly distributed throughout the state. BLB tested positive for Bean pod mottle virus (BPMV) in 37 of 41 counties assayed in 2000. In 2001, BLB tested positive for BPMV in 86 of 99 counties sampled. In 2000 and 2001, western corn rootworm (WCR; Diabrotica virgifera virgifera) adults were abundant in soybean fields only in east central Illinois. WCR adults tested positive for BPMV in 21 of 21 east central Illinois counties in 2000 and 20 of 24 sampled in 2001. BPMV was detected in soybean plants in 38 of 46 counties sampled in 2000. Field-collected WCR adults transmitted BPMV to potted soybean plants at low rates either directly from BPMV-infected soybean fields or with prior feeding on BPMVinfected plants. This is the first report of the distribution of BLB, WCR adults, and BPMV in Illinois and of BPMV transmission by adult WCR.

Bean pod mottle virus (BPMV; genus Comovirus, family Comoviridae) is a beetle-transmitted virus that infects soybean (1). The virus appeared in the Midwest during the late 1960 s and early 1970 s $(4,12)$. The first occurrence of BPMV in Illinois was documented in 1975 (15). Since that time, further information on BPMV incidence and distribution in Illinois has not been reported. A recent feature article on BPMV provides an overview about the virus, some of its vectors, and management of both (6).

The symptoms of BPMV infection of soybean include green to yellow mottling in the upper leaves and leaf puckering and distortion (1). Yield losses are primarily due to decreased pod formation and re-

Corresponding author: G. L. Hartman

E-mail: ghartman@uiuc.edu

Trade and manufacturers' names are necessary to report factually on available data; however, the USDA neither guarantees nor warrants the standard of the product, and the use of the name by USDA implies no approval of the product to the exclusion of others that may also be suitable.

Accepted for publication 16 May 2003.

Publication no. D-2003-0718-02R

This article is in the public domain and not copyrightable. It may be freely reprinted with customary crediting of the source. The American Phytopathological Society, 2003. duced seed size, weight, and number (16). Seed coat mottling caused by BPMV is also responsible for losses, particularly in food grade soybean that may be rejected due to discolored seed. When severe foliar symptoms occur, the virus can cause yield losses up to $52 \%$ depending on the cultivar $(8,9)$. BPMV also acts synergistically with Soybean mosaic virus (genus Potyvirus, family Potyviridae) to further reduce yields (19).

The primary vector of BPMV is the bean leaf beetle (BLB; Cerotoma trifurcata), an insect native to North America; although other vectors are known, including the southern corn rootworm/spotted cucumber beetle (Diabrotica undecimpunctata howardi), striped blister beetle (Epicauta vittata), and grape colaspis (Colaspis brunnea) (1). BLB are efficient vectors of BPMV (20) and are common in soybean fields throughout Illinois (11). BLB are likely responsible for much of the localized spread of BPMV and may contribute to longer distance BPMV spread related to seasonal flight behavior. The occurrence of BPMV in BLB can be readily detected by enzyme-linked immunosorbent assay (ELISA) $(3,5)$.

The occurrence of BPMV in soybean fields early in the growing season may result from transmission by overwintered BLB adults that acquired BPMV from the previous cropping season or from early spring feeding on BPMV-infected peren- nial weed hosts, and/or planting of infected seed $(1,14,23)$. In Illinois there are two BLB generations per year (7). The firstgeneration insects are the offspring of the overwintering population previously emerging from the shelter of wooded areas and crop residues in the spring to feed on young soybean plants and deposit eggs in soybean fields. Adults of the first generation emerge beginning in midseason and feed on more mature soybean plants before depositing eggs that give rise to the second generation of BLB. These beetles feed in soybean fields until the plants senesce, whereupon they seek sheltered sites in which to overwinter.

Although the southern corn rootworm/spotted cucumber beetle is a known vector of BPMV (1), the closely related western corn rootworm (WCR; Diabrotica virgifera virgifera), a corn pest that occurs throughout corn-growing regions of the United States, previously has not been reported to be a vector of BPMV, although it has been reported as a vector of the related comoviruses Cowpea mosaic virus, Cowpea severe mosaic virus, and Squash mosaic virus, as well as the non-comovirus Maize chlorotic mottle virus (2). Adult WCR are especially abundant across a large portion of east central Illinois and much of Indiana, and parts of Ohio and Michigan (13), and frequently are the most abundant beetle in soybean fields. The abundance of WCR adults in this region, which is expanding in size, is due to the circumvention of crop rotation resulting from an evolutionary shift toward a broadened ovipositional range (13). WCR adults in these areas still emerge in cornfields where they feed and mate, but after mating they begin leaving cornfields and fly between corn and other nearby fields (predominantly soybean). Once in soybean fields, WCR adults lay eggs and feed on soybean foliage. The physical damage caused by WCR adults feeding on soybean was not shown to significantly affect yield (13). However, WCR adults could reduce yield if, by virtue of their short and long distance dispersal abilities, they were capable of quickly spreading viruses within and between soybean fields $(10,13)$. The threat posed by large numbers of WCR adults feeding in soybean and their potential to vector BPMV raises concerns about the local and long-distance spread of 
BPMV within and beyond areas where BPMV is common.

Until recently, statewide monitoring of soybean pests and viruses was not systematically documented in Illinois. Over the last several years, changes in prevalence and distribution of various soybean diseases and soybean insect pests that could vector plant viruses has stimulated new interest in using the statewide monitoring program to track insect-vectored plant diseases. The objectives of this study were to (i) determine the distribution of bean leaf beetles and adult western corn rootworms and the occurrence of BPMV in these insects and soybean plants collected from soybean fields throughout Illinois, and (ii) test BPMV transmission of several soybean-feeding beetles.

\section{MATERIALS AND METHODS}

BPMV detection. Beetles and plants were tested for the presence of BPMV using a commercial double antibody sand-
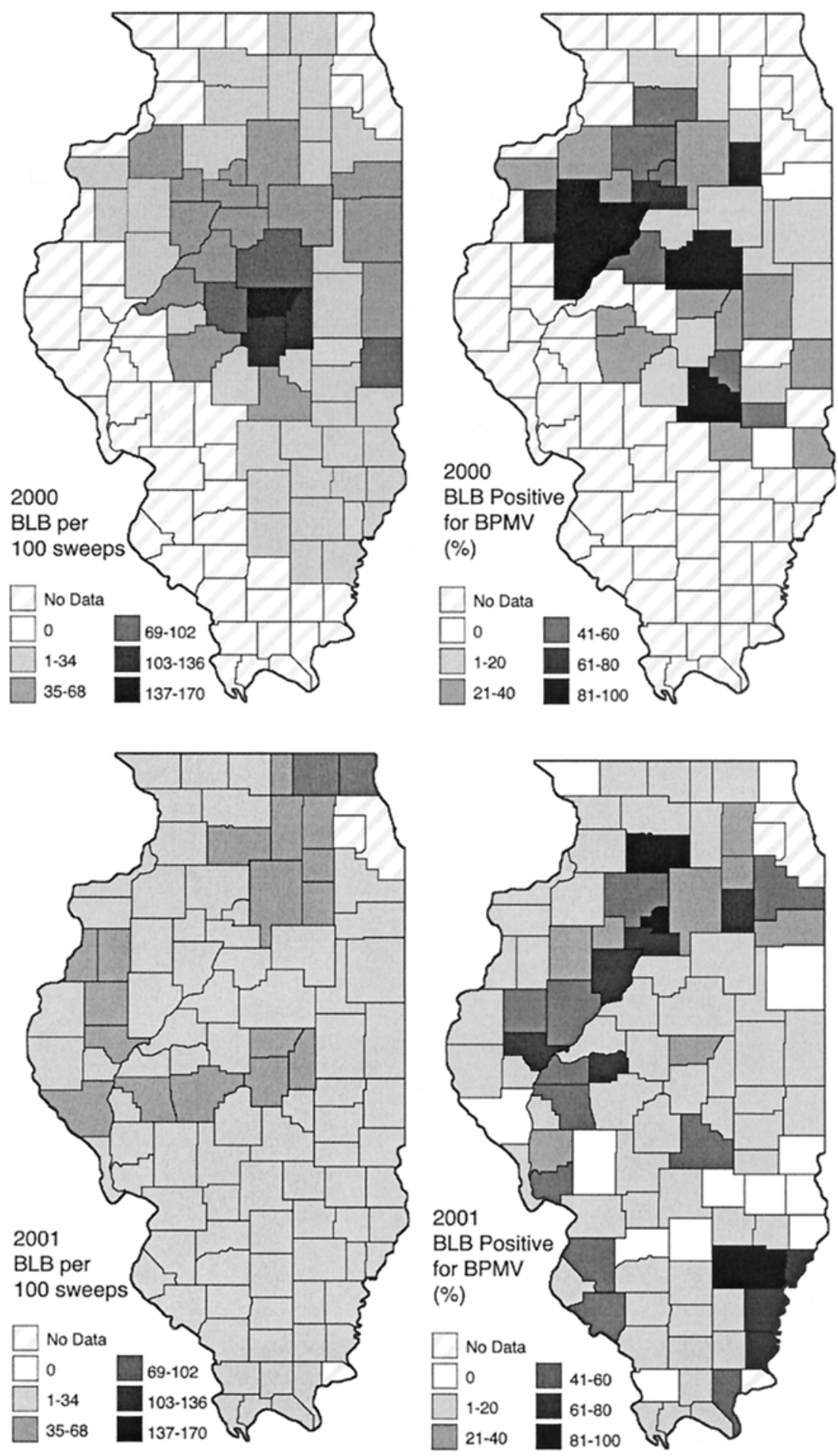

Fig. 1. Distribution of bean leaf beetles (BLB) and percentage of beetles that were Bean pod mottle virus (BPMV) enzyme-linked immunosorbent assay (ELISA)-positive in soybean fields in 2000 and 2001. wich ELISA kit and the protocol provided (Agdia Reagent Set, Alkaline phosphatase label; Agdia, Inc., Elkhart, IN). Absorbance was read at $405 \mathrm{~nm}$ using a Biotek EL 340 plate reader. Adult beetles were ground individually with pellet pestles in $0.2-\mathrm{ml}$ extraction buffer in $1.5-\mathrm{ml}$ microcentrifuge tubes. Incubation periods and temperatures for ELISA steps were: overnight at $5^{\circ} \mathrm{C}$ for coating antibodies, $2 \mathrm{~h}$ at room temperature for samples, and $2 \mathrm{~h}$ at room temperature for enzyme-labeled antibody conjugates. Absorbance values of greater than three times the lowest beetle extract absorbance (which were usually about 0.06 to 0.07 , similar to wells with no samples) were recorded as positive for BPMV detection. These positive thresholds of about 0.18 to 0.21 , depending on the plates, were used to make a conservative estimate of beetles carrying BPMV in their bodies. This is because the absorbance from beetles would be expected to represent a continuum based on the amount of BPMV tissue consumed and/or how recently it was consumed. Plant samples were ground with a Meku Erich Pollahne leaf roller homogenizer using about $1 \mathrm{ml}$ of extraction buffer per sample. An absorbance of greater than 0.2 at $405 \mathrm{~nm}$ was considered positive for the presence of BPMV in the soybean leaf samples. Negative values on average were less than 0.1. Extensive experience using the Agdia BPMV ELISA kit with soybean leaf samples indicated that wells containing uninfected samples had absorbance values of 0.1 or less after a 20 - to $30-\mathrm{min}$ substrate ( $p$-nitrophenyl phosphate; 1 $\mathrm{mg} / \mathrm{ml}$ ) incubation time. Therefore, sample wells with absorbance values of 0.2 or more (two times the negative control) were considered positive. Positive controls in all ELISAs were extracts from BPMVinfected soybean leaves.

Survey of Illinois counties for bean leaf beetles, western corn rootworm beetles, and BPMV. On 27 July and 2 August 2000, two nearby soybean fields at three randomly chosen locations in each of 58 counties were selected to collect beetles. The fields often differed in planting date, soybean cultivar, and other cultural practices. One hundred sweeps of an insect net were taken at each site. Collected insects were immediately placed on dry ice for transport. Insects were sorted, counted, and stored at $-80^{\circ} \mathrm{C}$. Collections containing a minimum of $10 \mathrm{WCR}$ adults or 10 BLB were used to test for the presence of BPMV with ELISA; up to 20 individuals of each species were tested when available. Only one collection of each species was tested from each county.

All but three counties (Cook, DuPage, and Hardin) were sampled in 2001. In or near areas where medium to high populations of WCR adults commonly occur in soybean fields (north, northeast, central, and east central Illinois counties), two nearby soybean fields at three randomly 
chosen locations were sampled. When possible, beetles from the same field were used for the analysis with 20 WCR adults and 20 BLB from each of two collections used for these counties. In the counties from other Illinois regions with low populations of WCR adults in soybean fields, two nearby fields at two locations were sampled. At least 10 and as many as 20 of each species of beetle from a single collection site in each of these counties were used to test for BPMV using ELISA. Beetles were collected, stored, and assayed as previously described.

Soybean leaf samples were collected from plants within the outer 20 rows of soybean fields in 46 Illinois counties on 2 August 2000. They were stored frozen at $-20^{\circ} \mathrm{C}$ until tested for BPMV by ELISA. For most counties, samples were collected from a few fields; 15 to 25 fields were sampled in LaSalle, Champaign, and Clay counties, representing north, central, and southern portions of Illinois.

In 2001, leaf samples were collected from 99 counties. A sample consisted of three randomly selected leaves from each field. Samples were collected from two to six fields per county. Leaves were placed between $7 \times 12 \mathrm{~cm}$ index cards in plastic bags kept on dry ice during transport to the laboratory and then stored at $-80^{\circ} \mathrm{C}$ until ELISA testing. Additional leaf samples were collected from 32 Illinois counties surveyed for aphid-transmitted virus distribution in August and September; another set of leaves included counties in the northern half of Illinois surveyed for fungal diseases in early September.

Transmission test of BPMV by laboratory-reared western corn rootworm adults. WCR adults (diapausing strain) reared at the USDA Northern Grain Insects Research Laboratory at Brookings, SD, were obtained for laboratory BPMV transmission tests. Beetles were caged on BPMV-infected cv. Williams 82 soybean that had been mechanically inoculated 3 weeks prior to insect introduction. Mechanical inoculation involved maceration of BPMV-infected soybean leaves in sterilized mortars and pestles containing cold $0.025 \mathrm{M}$ potassium phosphate buffer $(\mathrm{pH}$ 7.1) plus $0.01 \mathrm{M}$ sodium sulfite. Virusinfected soybean leaf extract was then spread over Carborundum-dusted leaves of healthy Williams 82 seedlings. After 2 days of virus acquisition access, WCR were removed and placed on caged healthy 2-week-old Williams 82 soybean seedlings for 2 days of inoculation access feeding. In each of three separate experiments, approximately 180 beetles were allowed to feed on about 50 soybean inoculation access plants per experiment. Beetles and plants were distributed among six, $0.3 \mathrm{~m}$ per side, cubical cages (two plants per pot and four pots per cage). Two negative control groups of beetles were kept on corn ( $n$ $=10$ to 20$)$ or on healthy soybean $(n=14$ to 20) plants, and were frozen $\left(-80^{\circ} \mathrm{C}\right)$ at the beginning of each experiment. Another control group ( $n=14$ to 28 ) was frozen immediately after the virus acquisition access feed but prior to the inoculation access feeding. Beetles that survived to the end of the 2-day inoculation access feeding were frozen and stored until tested by ELISA. Approximately 3 weeks after the inoculation access feeding, leaves of soybean inoculation access plants were as-
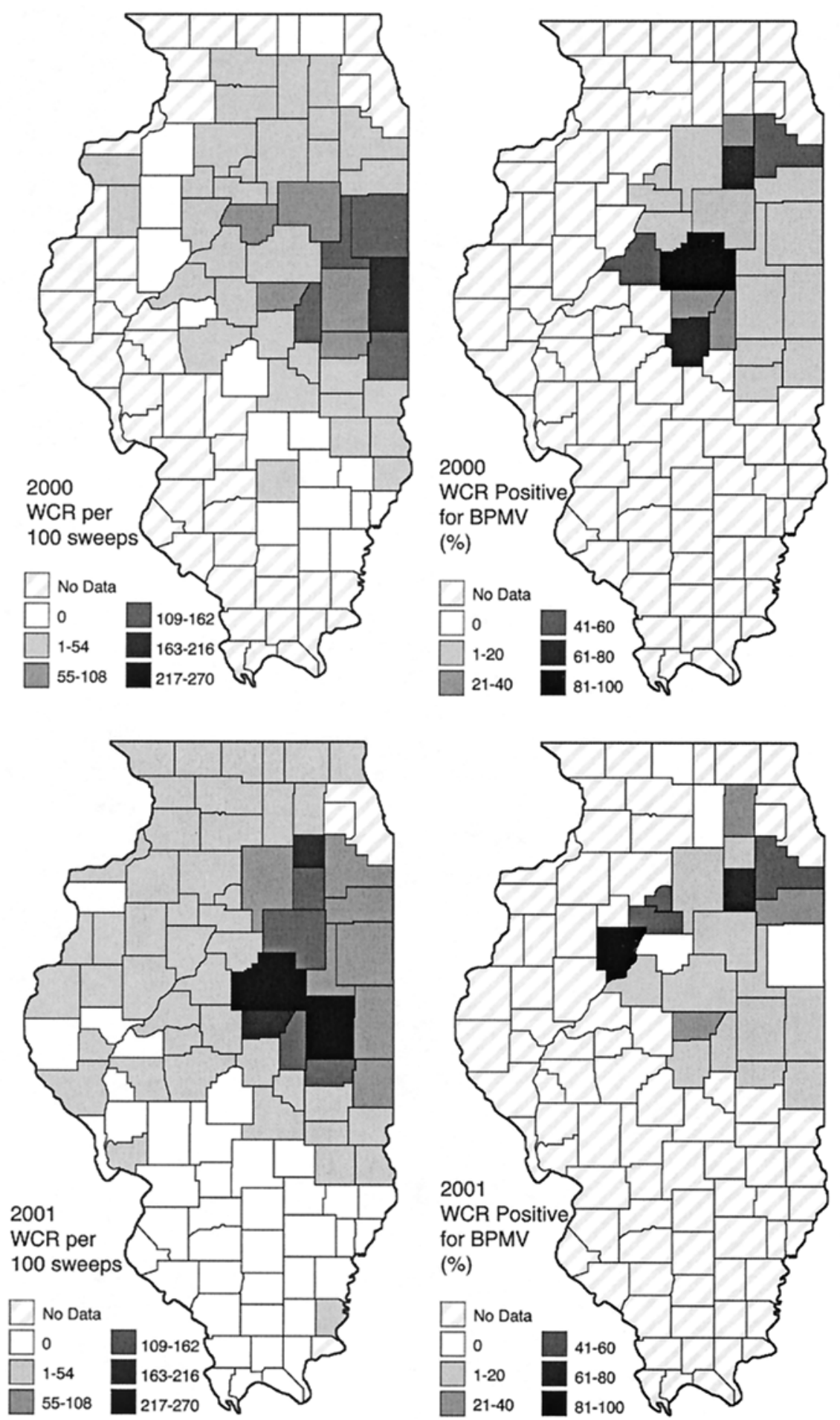

Fig. 2. Distribution of western corn rootworms (WCR) and percentage of beetles that were Bean pod mottle virus (BPMV) enzyme-linked immunosorbent assay (ELISA)-positive in soybean fields in 2000 and 2001.

sayed for the presence of BPMV, as described for plant samples in the $B P M V$ detection section.

Transmission test of BPMV by fieldcollected beetles. Adult BLB and WCR adults were collected from soybean fields at the University of Illinois Crop Sciences Research and Education Center in Urbana in early September 2000. Beetles were placed in groups of three to seven on two to three healthy caged potted plants of cv.

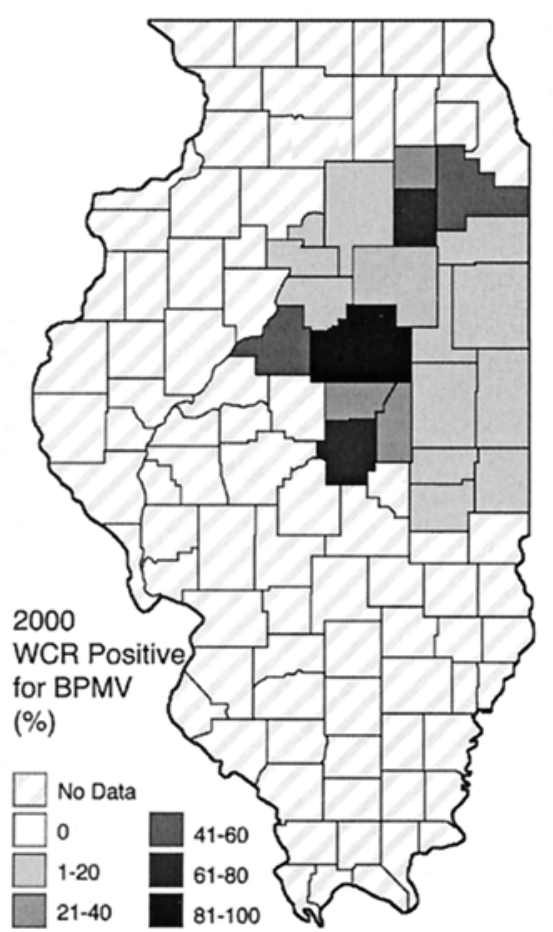


Williams 82. Beetles were removed after 2 days, and inoculation access plants were maintained for 3 weeks in a greenhouse or growth chamber before testing by ELISA for BPMV transmission.

In July and August 2001, adults of WCR, Japanese beetles, and blister beetles were collected from soybean fields, placed on BPMV-infected soybean leaves for 1 to 2 days, transferred to greenhouse-grown soybean seedlings for 1 to 2 days, and removed. The inoculation access plants were maintained for 3 weeks in a greenhouse or growth chamber before being assayed by ELISA.

Overwintering BLB were collected in early April 2001 in wooded areas of Champaign County, IL. They were placed in groups of five to nine in caged pots con- taining two to three greenhouse-grown healthy soybean plants of cvs. IA1006 or Williams 82. Adults were allowed to feed for 2 to 3 days and then were frozen at $-20^{\circ} \mathrm{C}$. The inoculation access plants were maintained for 3 weeks prior to testing for BPMV infection with ELISA.

BPMV isolates. Three BPMV isolates were used in the beetle transmission tests in which beetles were given access to mechanically inoculated virus-infected soybean plants or leaves. All of the isolates, BPMV 98 and BPMV W-6 from Champaign County and BPMV 3-2 from Peoria County, were from soybean. Isolates were maintained in dried plant material at $5^{\circ} \mathrm{C}$ over anhydrous calcium sulfate desiccant, and through periodic transfer by mechanical inoculation in a greenhouse. Isolate

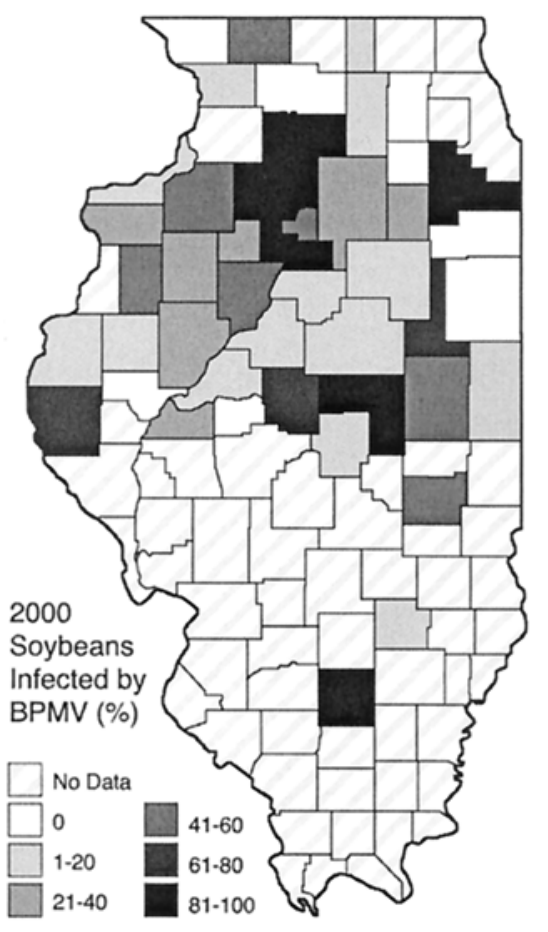

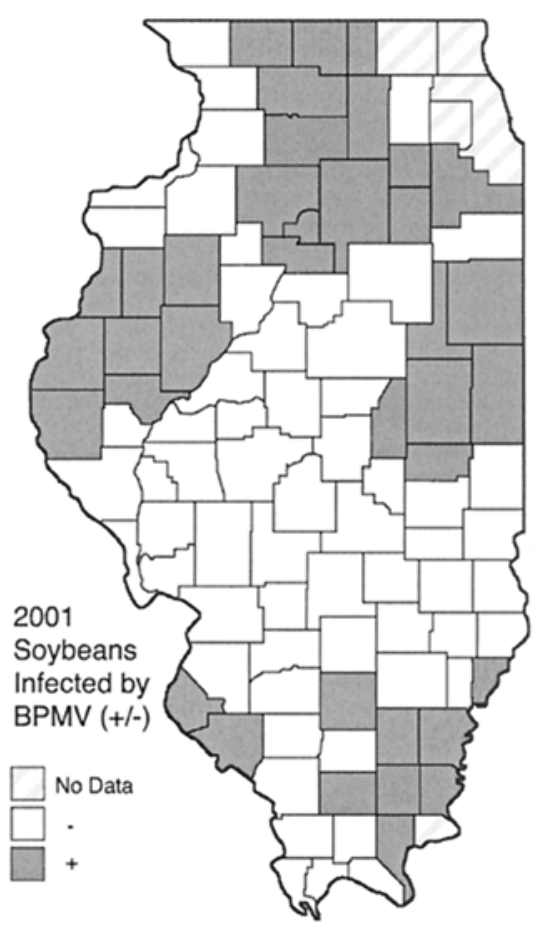

Fig. 3. Distribution by Illinois counties of Bean pod mottle virus (BPMV) sampled from soybean plants in 2000 and 2001.

Table 1. Summary of Bean pod mottle virus (BPMV) transmission to soybean using as vectors various beetle species present in Illinois

\begin{tabular}{|c|c|c|c|c|}
\hline Beetle & $\begin{array}{l}\text { Beetles per } \\
\text { test plant }\end{array}$ & Conditions & $\begin{array}{c}\text { Plants } \\
\text { infected }\end{array}$ & $\begin{array}{l}\text { Total plants } \\
\text { infested }\end{array}$ \\
\hline Bean leaf beetle & 2 & $\begin{array}{l}\text { Field collected from soybean; no } \\
\text { BPMV acquisition feeding }\end{array}$ & 9 & 14 \\
\hline Bean leaf beetle & $2-3$ & $\begin{array}{l}\text { Overwintered, collected from } \\
\text { trash/clothing in early spring; no } \\
\text { BPMV acquisition feeding }\end{array}$ & 1 & 95 \\
\hline Blister beetle & 1 & $\begin{array}{l}\text { Field collected from soybean; } \\
\text { BPMV acquisition feeding }\end{array}$ & 1 & 9 \\
\hline Japanese beetle & $1-2$ & $\begin{array}{l}\text { Field collected from soybean; } \\
\text { BPMV acquisition feeding }\end{array}$ & 0 & 60 \\
\hline $\begin{array}{l}\text { Western corn } \\
\text { rootworm }\end{array}$ & 4 & $\begin{array}{l}\text { Laboratory reared; BPMV } \\
\text { acquisition feeding }\end{array}$ & 0 & 165 \\
\hline $\begin{array}{l}\text { Western corn } \\
\text { rootworm }\end{array}$ & 2 & $\begin{array}{l}\text { Field collected from soybean; no } \\
\text { BPMV acquisition feeding }\end{array}$ & 1 & 16 \\
\hline $\begin{array}{l}\text { Western corn } \\
\text { rootworm }\end{array}$ & $2-3$ & $\begin{array}{l}\text { Field collected from soybean; } \\
\text { BPMV acquisition feeding }\end{array}$ & 1 & 52 \\
\hline
\end{tabular}

BPMV 3-2 was used in the blister beetle test, Japanese beetle test, and the tests using field-collected WCR adults with laboratory virus acquisition. Isolate BPMV 98 was used in the first two trials of laboratory-reared WCR adults, and isolate BPMV W6 was used in the third trial.

\section{RESULTS}

Survey of Illinois counties for BLB, WCR beetles, and BPMV. In 2000, BLB were present in soybean fields in all 58 counties sampled, with the highest numbers collected from the central portion of the state (Fig. 1). BPMV was detected in BLB in 37 of the 41 counties assayed, with the percentage of individuals carrying BPMV ranging from 5 to $100 \%$ (Fig. 1). In 2001, BLB were present in all 99 counties sampled, and BPMV was detected in BLB collected in 86 of the 99 counties sampled, with 5 to $100 \%$ of the beetles carrying BPMV (Fig. 1).

In 2000, WCR adults were abundant only in soybean fields in a distinct region of east central Illinois (Fig. 2). BPMV was detected in WCR adults in 21 of the 21 counties assayed, with 5 to $95 \%$ of the beetles carrying BPMV (Fig. 2). In 2001, WCR adults were only abundant in soybean fields in east central Illinois counties, as in 2000 (Fig. 2). Approximately 5 to $86 \%$ of the WCR adults carried BPMV in 20 counties, and BPMV was not detected in WCR adults in four counties (Fig. 2). There was a positive correlation $(r=0.9, P$ $<0.0001)$ of BPMV detection between BLB and WCR adults.

In 2000, BPMV was detected in soybean plants in 38 of the 46 counties sampled (Fig. 3). Incidence in the samples varied from 0 to $100 \%$. BPMV was detected in 42,2 , and $22 \%$ of the plant samples from Champaign, Clay, and La Salle counties, respectively. In 2001, BPMV was detected in fewer leaf samples, and the representative data are expressed only as either positive or negative for each county (Fig. 3).

Transmission test of BPMV by laboratory-reared WCR adults. Laboratoryreared WCR adults failed to transmit BPMV to a total of 165 test plants in three tests (Table 1), even though feeding was substantial in both virus acquisition access and inoculation access periods. Beetles frozen prior to beginning the transmission tests or frozen after feeding on healthy soybean leaves did not contain BPMV, as assayed by ELISA. When frozen after virus acquisition feeding access on BPMVinfected plants, there were ELISA-positive beetles in all three tests $(8 / 14,7 / 17,11 / 28)$. Likewise, when frozen after the end of the inoculation access periods, there were ELISA-positive beetles in all three tests (66/124, 50/162, 26/154).

Transmission tests of BPMV by fieldcollected beetles. BLB collected in early September from soybean fields at the University of Illinois Research Center at Ur- 
bana transmitted BPMV to 9 of 14 soybean test plants, while WCR beetles transmitted to 1 of 16 soybean test plants (Table 1).

WCR adults collected from the field and allowed to feed on BPMV-infected leaves in the laboratory transmitted BPMV to 1 of 52 healthy soybean seedlings (Table 1). Field-collected Japanese beetles given laboratory virus acquisition access did not transmit BPMV, whereas blister beetles transmitted BPMV to one of nine soybean plants (Table 1).

Overwintering BLB transmitted to 1 of 95 test plants (Table 1). Of the 227 beetles frozen after inoculation access feeding, 53 (23\%) were ELISA-positive for BPMV.

\section{DISCUSSION}

The state survey data indicated that BLB were common in soybean fields in Illinois in 2000 and 2001. The occurrence of BPMV-positive BLB was highest in counties near the Illinois and Wabash rivers in 2001. Although additional data may be needed to determine if this is a consistent pattern, one explanation may be that wooded areas adjacent to river systems may provide protection and resources for BLB that increase winter survival and opportunity for early-season BPMV transmission of virus overwintering in beetles or in weed hosts.

Mueller and Haddox (16) found that as the mean number of BLB increased, there was a concomitant increase of viruliferous BLB and BPMV in plant samples. In our study, there was a strong positive correlation between percent BPMV ELISApositive WCR individuals and percent BLB individuals that were BPMV ELISApositive in the locations sampled. Percent BPMV-positive individual beetles presumably reflected local BPMV incidence in soybean. Ghabrial et al. (3) used ELISA absorbances of bulked BLB samples to gauge BPMV incidence in soybean fields from which the beetles were collected.

WCR adults were abundant in soybean fields in only a distinct region of east central Illinois where the practice of crop rotation recently failed to control root damage caused by the WCR larvae to first-year corn (13). The population of WCR adults was higher than BLB in that region, making them the most abundant beetle in soybean fields. The increased egg laying in and feeding on soybean plants in east central Illinois and several other locations may increase the importance of this insect as a BPMV vector. While the results indicated that BLB had a higher rate of BPMV transmission than WCR adults, the overwhelming numbers of WCR feeding in soybean may result in a significant number of plants becoming infected with BPMV. The rates of BPMV transmission by WCR adults were similar to that reported for adult southern corn rootworm/spotted cucumber beetles (Diabrotica undecimpunctata howardi) (20). In addition to this first report of WCR adults being able to transmit BPMV, they also are known to vector other comoviruses, as well as Maize chlorotic mottle virus (2).

WCR adults do not have any direct effect on soybean yield (13), but they may be able to transmit BPMV early enough in the season to cause significant yield losses in later planted soybean, based on timing of BPMV infection research from another study (21). The mobility of the WCR adults also could result in increased spread of BPMV both within and between soybean fields, since WCR adults' movement is much greater than that of BLB, which generally are restricted in movement (22).

Striped blister beetle populations are increasing in some areas of Illinois. Our results confirmed that the striped blister beetles are capable of transmitting BPMV, as previously reported (18). Although Japanese beetles are common in some soybean fields in counties of east central Illinois, the species failed to transmit BPMV in our tests. In transmission tests, Japanese beetles also failed to transmit Maize chlorotic mottle virus (17).

In summary, BLB were found throughout Illinois, while the WCR adults were more localized in the east central part of the state. Both beetles can harbor and transmit BPMV. BPMV was found widely distributed in the state, and field-collected WCR adults transmitted BPMV to potted soybean plants at a low rate when brought directly from BPMV-infected soybean fields or when fed on BPMV-infected leaves prior to inoculation access feeding.

\section{ACKNOWLEDGMENTS}

We would like to thank all the individuals who helped with the collection of samples for testing, Curt Hill for his review of the manuscript, and the Illinois Soybean Check-Off Board and the North Central Soybean Research Program for their support of this research.

\section{LITERATURE CITED}

1. Gergerich, R. C. 1999. Bean pod mottle. Pages 61-62 in: Compendium of Soybean Diseases. 4th ed. G. L. Hartman, J. B. Sinclair, and J. C. Rupe, eds. American Phytopathological Society, St. Paul, MN.

2. Gergerich, R. C., Scott, H. A., and Fulton, J. P. 1986. Evaluation of Diabrotica beetles as vectors of plant viruses. Pages 227-249 in: Methods for the Study of the Pest Diabrotica. J. L. Krysan and T. A. Miller, eds. SpringerVerlag, New York.

3. Ghabrial, S. A., Hershman, D. E., Johnson, D. W., and Yan, D. 1990. Distribution of bean pod mottle virus in soybeans in Kentucky. Plant Dis. 74:132-134.

4. Ghabrial, S. A., Pickard, C. M., and Stuckey, R. E. 1977. Identification and distribution of virus diseases of soybean in Kentucky. Plant Dis. Rep. 61:690-694.

5. Ghabrial, S. A., and Schultz, F. J. 1983. Serological detection of bean pod mottle virus in bean leaf beetles. Phytopathology 73:480483.

6. Giesler, L. J., Ghabrial, S. A., Hunt, T. E., and Hill, J. H. 2002. Bean pod mottle virus: A threat to U.S. soybean production. Plant Dis. 86:1280-1289.

7. Helm, C. G., Jeffords, M. R., Post, S. L., and Kogan, M. 1983. Spring feeding activity of overwintered bean leaf beetles (Coleoptera: Chrysomelidae) on nonleguminous hosts. Environ. Entomol. 12:321-322.

8. Hopkins, J. D., and Mueller, A. J. 1984. Effect of bean pod mottle virus on soybean yield. J. Econ. Entomol. 77:943-947.

9. Horn, N. L., Newsom, L. D., and Jensen, R. L. 1973. Economic injury thresholds of bean pod mottle and tobacco ringspot virus infection of soybeans. Plant Dis. Rep. 57:811-813.

10. Isard, S. A., Nassar, M. A., Spencer, J. L., and Levine, E. 1999. The influence of weather on western corn rootworm flight activity at the borders of a soybean field in east central Ilinois. Aerobiologia 15:95-104.

11. Jeffords, M. R., Helm, C. G., and Kogan, M. 1983. Overwintering behavior and spring colonization of soybean by the bean leaf beetle (Coleoptera: Chrysomelidae) in Illinois. Environ. Entomol. 12:1459-1463.

12. Krell, R., and Rice, M. E. 2000. Beetles transmit a new soybean virus. Inter. Crop Manag. 484:43-45.

13. Levine, E., Spencer, J. L., Isard, S. A., Onstad, D. W., and Gray, M. E. 2002. Adaptation of the western corn rootworm to crop rotation: Evolution of a new strain in response to a management practice. Am. Entomol. 48:94107.

14. Lin, M. T., and Hill, J. H. 1983. Bean pod mottle virus: Occurrence in Nebraska and seed transmission in soybeans. Plant Dis. 67:230-233.

15. Milbrath, G. M., McLaughlin, M. R., and Goodman, R. M. 1975. Identification of bean pod mottle virus from naturally infected soybeans in Illinois. Plant Dis. Rep. 59:982-983.

16. Mueller, A. J., and Haddox, A. W. 1980. Observations on seasonal development of the bean leaf beetle Cerotoma trifurcata (Forster) and incidence of bean pod mottle virus in Arkansas soybean. J. Ga. Entomol. Soc. 15:398403.

17. Nault, L. R., Styer, W. E., Coffey, M. E., Gordon, D. T., Negi, L. S., and Niblett, C. L. 1978. Transmission of maize chlorotic mottle virus by chrysomelid beetles. Phytopathology 68:1071-1074.

18. Patel, V. C., and Pitre, H. N. 1971. Transmission of bean pod mottle virus to soybean by the striped blister beetle Epicauta vittata Plant Dis. Rep. 55:628-629.

19. Quiniones, S. S., Dunlevy, J. M., and Fisher, J. W. 1971. Performance of three soybean varieties inoculated with soybean mosaic virus and bean pod mottle virus. Crop Sci. 11:662664.

20. Ross, J. P. 1963. Transmission of bean pod mottle virus in soybean by beetles. Plant Dis Rep. 47:1049-1050.

21. Ross, J. P. 1986. Response of early- and lateplanted soybeans to natural infection by bean pod mottle virus. Plant Dis. 70:222-224.

22. Waldbauer, G. P., and Kogan, M. 1976. Bean leaf beetle: Phenological relationship with soybean in Illinois. Environ. Entomol. 5:3544.

23. Walters, H. J., and Lee, F. N. 1969. Transmission of bean pod mottle virus from Desmodium paniculatum to soybean by the bean leaf beetle. Plant Dis. Rep. 53:411. 